\title{
Meningkatkan kompetensi profesional guru dengan pelatihan pembelajaran matematika realistik
}

\author{
Usman Mulbar ${ }^{1}$, Ilham Minggi ${ }^{2}$, Ahmad Zaki $^{3}$ \\ ${ }^{1,2,3}$ Fakultas MIPA, Universitas Negeri Makassar
}

\begin{abstract}
The PKM progra $m$ is ca rried out with the method of providing training and guidance to participants on realistic mathematics learning to improve teacher competence in implementing lea rning with the aim of (1) to increa se knowledge about realistic mathematics learning, (2) participants can im ple ment re a listic mathematic s learning in the learning process, and (3) participants can disseminate or disseminate realistic mathematics learning knowledge. The main targeta udience for the PKM Program activities are school supervisors, sch ool principals a nd school teachers in Tinggimoncong sub-district, Gowa district, South Sula wesi province. The results obtained in PKM program activities are increasing knowledge and realistic mathematics learning concepts of PKM program participants, increasing the skills of developing realistic mathematics learning skills in PKM progra m part ic ipants, PKM progra $m$ participants can make examples and arrange realistic mathematics learn in $\mathrm{g}$ a ctivities in lea rning classes, and PKM program participants can implementing rea listic mathematics learning in le a rning in sch ools. Other results obtained were increased motivation of participants in knowing realistic mathematics lea rning materials and high enthusiasm of participants in disseminating or disseminating PKM program results, es pecially realistic mathematics learning materials. Outputs of PKM activities a re (1) increasing participa nt's kn owledge rega rding activity materials, (2) scientific articles published at national seminars, and (3) publications on PKM implementation on online media.
\end{abstract}

Key words: PKM Progra m, realistic mathematics learning, training \& guidance

\section{PENDAHULUAN}

Pendidikan memegang peranan penting dalam mempersiapkan sumber daya manusia yang berkualitas dan mampu berkompetisi dalam perkembangan ilmu pengetahuan dan teknologi, sehingga pendidikan harus dilaksanakan dengan sebaik-baiknya untuk memperoleh hasil maksimal. Pendidikan hendaknya dikelola, baik secara kualitas maupun kuantitas. Hal tersebut dapat dicapai dengan terlaksananya pendidikan yang tepat waktu dan tepat guna untuk mencapai tujuan pembelajaran.

Sejalan dengan upaya pengembangan ilmu pengetahuan dan teknologi, sekolah merupakan lembaga formal penyelenggara pendidikan. Sekolah Dasar (SD) sebagai salah satu lembaga formal dasar yang bernaung di bawah Departemen Pendidikan Nasional mengemban misi dasar dalam memberikan kontribusi untuk mencapai tujuan pendidikan nasional.

Pendidikan dilaksanakan dalam bentuk proses belajar mengajar yang merupakan pelaksanaan dari kurikulum sekolah. Melalui kegiatan pengajaran, siswa-siswi SD yang berada pada tahap operasi konkrit sudah semestinya dibekali dengan ilmu pengetahuan dasar dan keterampilan dasar yang dalam hal ini adalah mata pelajaran yang tercantum dalam kurikulum SD/MI untuk mengembangkan pengetahuan dan keterampilannya pada jenjang pendidikan selanjutnya.

Pengajaran di kelas tidak terlepas dari aktivitas belajar siswa. Melalui aktivitas belajar tersebut diharapkan dapat meningkatkan pengalaman belajar sehingga proses pembelajaran akan menjadi lebih bermakna bagi siswa. Pelaksanaannyapun harus dilaksanakan dengan pendekatan belajar yang relevan dengan paradigma pendidikan sekarang.

Paradigma baru pendidikan sekarang ini lebih menekankan pada peserta didik sebagai manusia yang memiliki potensi untuk belajar dan berkembang. Siswa harus aktif dalam pencarian dan pengembangan pengetahuan. Melalui paradigma baru tersebut diharapkan di kelas siswa aktif 
dalam belajar, aktif berdiskusi, berani menyampaikan gagasan dan menerima gagasan dari orang lain dan memiliki kepercayaan diri yang tinggi. Pendidikan Matematika Realistik Indonesia (PMRI) merupakan pendekatan dalam pembelajar an matematika yang sesuai dengan paradigma pendidikan sekarang. PMRI menginginkan adanya perubahan dalam paradigma pem-belajaran, yaitu dari paradigma mengajar menjadi paradigma belajar.

PMRI selama ini merupakan sebuah pendekatan pembelajaran matematika yang relatif baru dan belum semua kalangan dalam dunia pendidikan mengenalnya. Selama beberapa tahun belakangan sampai sekarang. PMRI telah diuji coba terbatas di kelas I, II dan III. Kemudian mulai tahun pelajaran 2002/2003 baru dilakukan uji coba penuh di beberapa Sekolah Dasar (SD) dan Madrasah Ibtidaiyah (MI) di Indonesia dengan hasil yang sangat menggembirakan. Saat ini pembelajaran matematika dengan pendekatan realistik untuk kelas lainnya masih diujicobakan.

Pembelajaran matematika selama ini terlalu dipengaruhi pandangan bahwa matematika adalah alat yang siap pakai. Pandangan ini mendorong guru bersikap cenderung memberi tahu konsep/ sifat/teorema dan cara menggunakannya. Guru cenderung mentransfer pengetahuan yang dimiliki ke pikiran anak dan anak menerimanya secara pasif dan tidak kritis. Adakalanya siswa menjaw ab soal dengan benar namun mereka tidak dapat mengungkapkan alasan atas jawaban mereka. Siswa dapat menggunakan rumus tetapi tidak tahu dari mana asalnya rumus itu dan mengapa rumus itu digunakan. Keadaan demikian mungkin terjadi karena di dalam proses pembelajaran tersebut siswa kurang diberi kesempatan dalam mengungkapkan ide-ide dan alasan jawaban mereka sehingga kurang terbiasa untuk mengungkapkan ide-ide atau alasan dari jawabannya.

Perubahan cara berpikir yang perlu sejak awal diperhatikan ialah bahwa hasil belajar siswa meruapakan tanggung jawab siswa sendiri. Artinya bahwa hasil belajar siswa dipengaruhi secara langsung oleh karakteristik siswa sendiri dan pengalaman belajarnya. Tanggung jawab langsung guru sebenarnya pada penciptaan kondisi belajar yang memungkinkan siswa memperoleh pengalaman belajar yang baik. Pengalaman belajar akan terbentuk apabila siswa ikut terlibat dalam pembelajaran yang terlihat dari aktivitas belajarnya.

PMRI juga menekankan untuk membawa matematika pada pengajaran bermakna dengan mengkaitkannya dalam kehidupan nyata seharihari yang bersifat realistik. Siswa disajikan masalah-masalah kontekstual, yaitu masalahmasalah yang berkaitan dengan situasi realistik. Kata realistik disini dimaksudkan sebagai suatu situasi yang dapat dibayangkan oleh siswa atau menggambarkan situasi dalam dunia nyata.

Sebagai gambaran guru sekolah di Kecamatan Tinggimoncong Kabupaten Gowa masih agak kurang dalam pemahaman pembelajaran matematika realistik sehingga tidak dapat mengaplikasikan dengan baik dalam pembelajaran di sekolah.

Salah satu solusi yang dapat dilakukan yaitu dengan upaya meningkatkan pengetahuan mengenai pembelajaran matematika realistik dan cara mengimplementasikan dengan baik dalam proses pembelajaran dapat dilakukan dengan Program Kemitraan Masyarakat (PKM). Oleh karena itu, untuk membantu peningkatan pengetahuan mengenai pembelajaran matematika realistik dan cara mengimplementasikan dengan baik dalam proses pembelajaran, maka Tim Dosen dari Universitas Negeri Makassar telah melakukan kegiatan Program Kemitraan Masyarakat (PKM) dengan judul PKM Guru Sekolah Dasar di Kabupaten Gowa Pelatihan Pembelajaran Matematika Realistik untuk Meningkatkan Kompetensi Guru Melaksanakan Pembelajaran.

\section{METODE PELAKSANAAN}

\section{A. Pembelajaran Matematika Realistik}

Model pembelajaran matematika realistik atau Realistic Mathematic Education (RME) adalah pendekatan pengajaran yang bertitik tolak pada hal- hal yang real bagi siswa.

Teori ini menekankan ketrampilan proses, berdiskusi dan berkolaborasi, berargumentasi 
dengan teman sekelas sehingga mereka dapat menemukan sendiri (Student Invonting), sebagai kebalikan dari guru memberi (Teaching Telling) dan pada akhirnya murid menggunakan matematika itu untuk menyeleseikan masalah baik secara individual ataupun kelompok.

Ide utama dari model pembelajaran matematika realistic/RME adalah manusia harus diberikan kesempatan untuk menemukan kembali (reinvent) ide dan konsep matematika dengan bimbingan orang dewasa (Gravemeijer).

Upaya untuk menemukan kembali ide dan konsep matematika ini dilakukan dengan memanfaatkan realita dan lingkungan yang dekat dengan anak. Soedjadi mengemukakan bahwa model pembelajaran matematika realistic pada dasarnya adalah pemanfaatan realita dan lingkungan yang dipahami peserta didik untuk memperlancar proses pembelajaran matematika secara lebih baik daripada masa yang lalu.

Lebih lanjut Soedjadi menjelaskan yang dimaksud dengan realita yaitu hal-hal yang nyata atau konkrit yang dapat diamati atau dipahami peserta didik lewat membayangkan, sedangkan yang dimaksud dengan lingkungan adalah lingkungan tempat peserta didik berada baik lingkungan sekolah, keluarga maupun masyarakat yang dapat dipahami peserta didik. Lingkungan ini disebut juga kehidupan sehari-hari.

Menurut De Lange dan Van Den Heuvel Parhizen, RME ini adalah pembelajaran yang mengacu pada konstruktifis sosial dan dikhususkan pada pendidikan matematika.

Model pembelajaran matematika realistik atau Realistik Mathematics Education (RME) pertama kali diperkenalkan dan dikembangkan di Belanda sejak tahun 1970 oleh institut Freudenthal dan menunjukan hasil yang baik, berdasarkan hasil The Third International Mathematics and Science Study (TIMSS) tahun 2000.

\section{B. Pelatihan dan Bimbingan}

Pelatihan adalah proses pendidikan jangka pendek yang menggunakan prosedur yang sistematis dan terorganisir. Selanjutnya, Udai menyatakan pelatihan dan pengembangan didefinisikan sebagai praktek jalan manusia yang fokus adalah mengidentifikasi, menilai dan melalui pembelajaran yang direncanakan membantu pengembangan kompetensi kunci yang memungkinkan orang untuk melakukan pekerjaan saat ini atau masa depan, kegiatan yang dirancang untuk meningkatkan kinerja manusia pada kerja karyawan adalah saat melakukan atau sedang disewa untuk melakukan.

Pelatihan juga merupakan upaya pembelajaran yang diselenggarakan oleh organisasi baik pemerintah, maupun lembaga swadaya masyarakat ataupun perusahaan dengan tujuan untuk memenuhi kebutuhan organisasi dan mencapai tujuan organisasi.

Pelatihan adalah upaya pembelajaran yang diselenggarakan oleh organisasi (instansi pemerintah, lembaga swadaya masyarakat, perusahaan) untuk memenuhi kebutuhan atau untuk mencapai tujuan organisasi sehingga pelatihan dapat diartikan sebagai kegiatan edukatif untuk membawa keadaan perilaku peserta pelatihan saat ini kepada perilaku yang lebih baik sebagaimana yang diinginkan oleh organisasi.

Pelatihan sebagai bagian dari pendidikan yang mengandung proses belajar untuk memperoleh dan meningkatkan keterampilan, waktu yang relatif singkat dan metode yang lebih mengutamakan praktek daripada teori.

\section{Metode Pelaksanaan Program Kemitraan Masyarakat (PKM)}

Metode pelaksanaan program PKM dilakukan dengan memberikan pelatihan dan bimbingan kepada peserta mengenai pembelajaran matematika realistik untuk meningkatkan kompetensi profesional guru dalam melaksanakan pembelajaran. Tujuan pelaksanaan PKM yaitu: (1) untuk meningkatkan pengetahuan mengenai pembelajaran matematika realistik, (2) peserta dapat mengimplementasikan dengan baik pembelajaran matematika realistik dalam proses pembelajaran, dan (3) peserta dapat menyebarluaskan atau mendiseminasikan pengetahuan pembelajaran matematika realistik. 
Materi yang disajikan dalam program PKM yaitu (Teori \& Konsep: Pembelajaran Matematika Realistik, Pengembangan dan Implementasi Pembelajaran Matematika Realistik, dan Implementasi Pembelajaran Matematika Realistik dalam Pembelajaran Di Sekolah. Dalam kegiatan praktek program PKM disajikan materi praktek pembelajaran matematika realistik.

Program PKM dilaksanakan di sekolah SD Negeri 2 Malino Kecamatan Tinggimoncong Kabupaten Gowa Provinsi Sulawesi Selatan pada hari hari Sabtu tanggal 24 Agustus 2019 sampai hari Jumat tanggal 30 Agustus 2019. Pelaksanaan program PKM mendapat sambutan dan dukungan dari pihak lainnya seperti Kepala Dinas Pendidikan Kabupaten Gowa, Koordinator Wilayah Pendidikan Kecamatan Tinggimoncong, Pengawas Sekolah dan Guru-guru sekolah.

Khalayak sasaran utama kegiatan Program PKM yaitu pengawas sekolah, kepala sekolah dan guru sekolah di kecamatan Tinggimoncong Kabupaten Gowa provinsi Sulawesi Selatan.

\section{HASIL DAN PEMBAHASAN}

Program kegiatan PKM merupakan kerjasama antara LPTK Universitas Negeri Makassar dengan berbagai pihak dalam ruang lingkup Dinas Pendidikan Kabupaten Gowa yakni Kepala Dinas Pendidikan Kabupaten Gowa, Koordinator Wilayah Pendidikan Kecamatan Tinggimoncong, Pengawas Sekolah Dasar, Kepala Sekolah, dan para Guru Sekolah Dasar di Kecamatan Tinggimoncong Kabupaten Gowa.

Materi yang disajikan dalam program PKM yaitu (Teori \& Konsep: Pembelajaran Matematika Realistik, Pengembangan dan Implementasi Pembelajaran Matematika Realistik, dan Implementasi Pembelajaran Matematika Realistik dalam Pembelajaran Di Sekolah. Dalam kegiatan praktek program PKM disajikan materi praktek pembelajaran matematika realistik.

Program PKM dilaksanakan di sekolah SD Negeri 2 Malino Kecamatan Tinggimoncong
Kabupaten Gowa Provinsi Sulawesi Selatan pada hari hari Sabtu tanggal 24 Agustus 2019 sampai hari Jumat tanggal 30 Agustus 2019. Pelaksanaan program PKM mendapat sambutan dan dukungan dari pihak lainnya seperti Kepala Dinas Pendidikan Kabupaten Gowa, Koordinator Wilayah Pendidik an Kecamatan Tinggimoncong, Pengawas Sekolah dan Guru-guru sekolah. Partisipasi dan dukungan seperti penyediaan tempat pelaksanaan program PKM dan penyediaan fasilitas kegiatan LCD, meja, papan tulis, printer, dan alat-alat praktek.

Narasumber dalam kegiatan program PKM merupakan narasumber ahli dan konsultan yang profesional sesuai dengan bidang kajian yang dilaksanakan. Beberapa dokumentasi kegiatan program PKM oleh narasumber sebagai berikut.
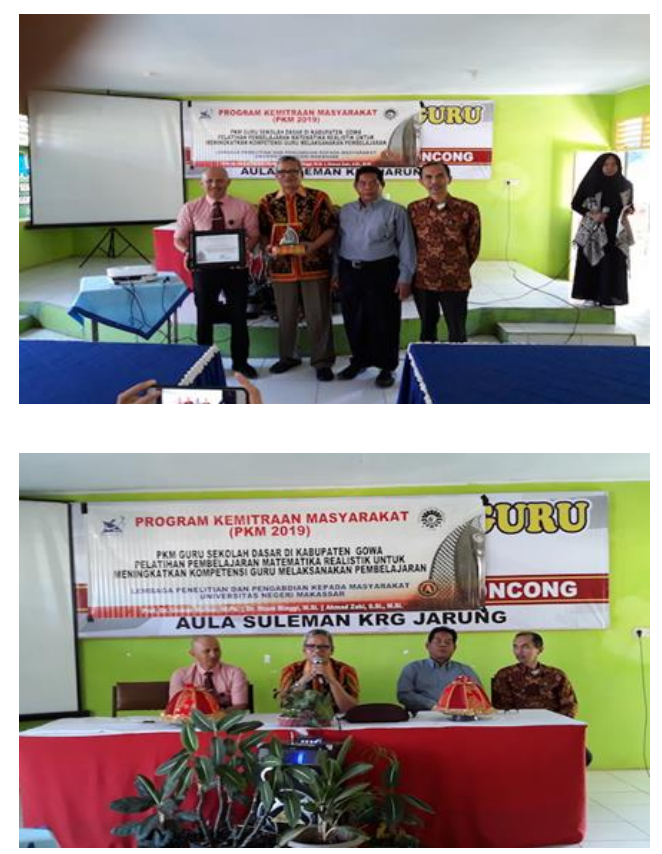

Gambar 1. Narasumber ahli program PKM

Peserta dalam program PKM sangat antusias dan termotivasi dalam mengikuti kegiatan. Dalam sesi diskusi dan kerja praktek juga ditunjukkan oleh peserta dengan antusiame dan motivasi yang tinggi. Beberapa dokumentasi kegiatan program PKM oleh peserta sebagai berikut. 

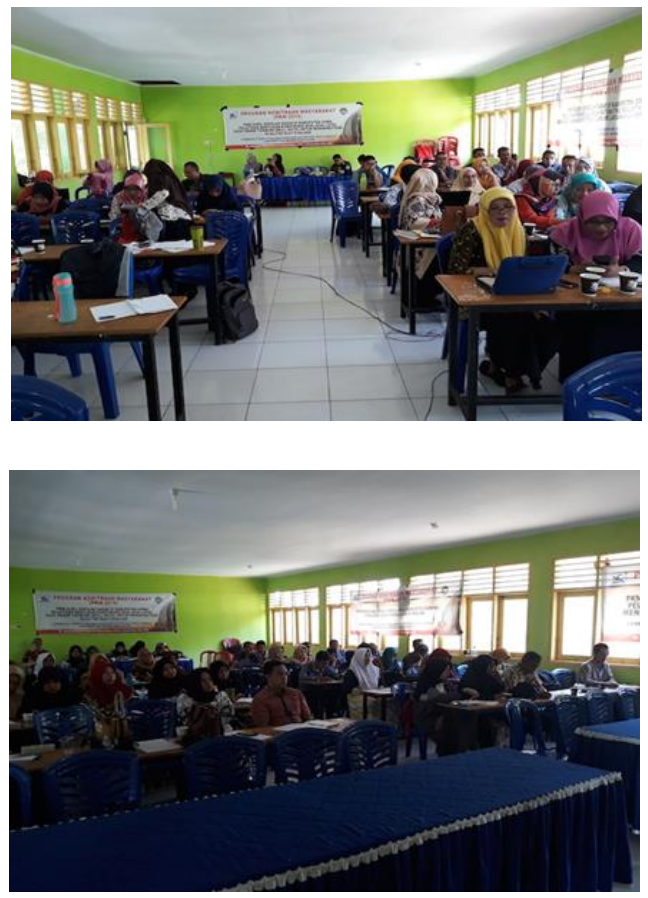

Gambar 2. Peserta program PKM

Hasil yang diperoleh dalam kegiatan program PKM yaitu meningkatnya pengetahuan dan konsep Pembelajaran Matematika Realistik peserta program PKM, meningkatnya keterampilan pengembangan Pembelajaran Matematika Realistik peserta program PKM, peserta program PKM dapat membuat contoh dan menyusun kegiatan Pembelajaran Matematika Realistik dalam kelas pembelajaran, dan peserta program PKM dapat mengimplementasikan Pembelajaran Matematika Realistik dalam pembelajaran di sekolah. Hasil lain yang diperoleh yaitu meningkatnya motivasi peserta dalam mengetahui materi Pembelajaran Matematika Realistik dan tingginya antusiasme peserta dalam menyebarluaskan atau mendiseminasikan hasil-hasil program PKM terutama materi Pembelajaran Matematika Realistik.

Hasil tersebut sejalan dengan hasil program PKM yang dilakukan oleh Alimuddin et al. (2018) dan Purnamawati et al. (2018) yang memperoleh hasil bahwa peserta kegiatan program PKM sang at bersemangat dalam mengetahui materi-materi kegiatan dan bekerja kelompok dalam kegiatan sesi praktek serta menyebarluaskan hasil-hasil pelaksanaan PKM kepada khalayak guru lainnya.

\section{KESIMPULAN}

Kesimpulan dalam pelaksanaan program PKM yaitu (1) meningkatnya pengetahuan dan konsep Pembelajaran Matematika Realistik peserta program PKM, (2) meningkatnya keterampilan pengembangan Pembelajaran Matematika Realistik peserta program PKM, (3) peserta program PKM dapat membuat contoh dan menyusun kegiatan Pembelajaran Matematika Realistik dalam kelas pembelajaran, dan (4) peserta program PKM dap at mengimplementasikan Pembelajaran Matematika Realistik Knowledge dalam pembelajaran di sekolah.

\section{DAFTAR PUSTAKA}

Alimuddin, Mulbar, U., Nasrullah. 2018. PKM Pembelajaran Matematika Realistik untuk Guru Sekolah Dasar. Laporan PKM LPM Universitas Negeri Makassar.

Purnamawati, Mulbar, U., Zaki, A. 2018. PKM Guru Sek olah di Kecamatan Tinggimoncong Pelatihan Penulisan Karya Tulis Ilmiah untuk Meningkatkan Profesionalisme Guru. Laporan PKM LPM Universitas Negeri Makassar. 